\title{
PELATIHAN PEMBUATAN ANEKA KREASI ABON BERBAHAN DASAR IKAN AIR TAWAR DESA BRINGKANG KECAMATAN MENGANTI KABUPATEN GRESIK
}

\author{
Diana Evawati ${ }^{1)}$, Yunus Karyanto ${ }^{2)}$, Susilowati ${ }^{3)}$ \\ FKIP Universitas PGRI Adi Buana Surabaya \\ Email : ${ }^{1}$ diana@unipasby,ac,id
}

\begin{abstract}
Abstrak
Tujuan dan Manfaat dari pelatihan ini untuk meneningkatan intake protein dengan pengolahan abon Ikan air tawar. Pengolahan hasil produksi ikan tawar/lele menjadi suatu komonditi yang dapat dijual dengan harga yang lebih tinggi dengan dibuat menjadi beberapa jenis olahan makanan berbahan dasar ikan lele yang memenuhi standart keamanan dan kesehatan pangan. Usaha ini diharapkan dapat dijadikan percontohan sehingga peternak yang lain ikut dapat menerapkan ditempat usahanya.Pemberdayaan keluarga ( ibu-ibu PKK) peternak lele dalam memperluas pemasaran dan untuk meningkatkan produktifitas. Daya terima abon ikan air tawar untuk uji organoleptik warna, aroma, tekstur dan rasa dengan lama pemanasan yang berbeda berpengaruh secara nyata. Dari hasil uji efektivitas untuk menentukan perlakuan terbaik dari pemanasan yang dilakukan, diperoleh abon ikan air tawar dengan lama pemanasan 30 menit.
\end{abstract}

Keyword : Ikan air tawar, Kalsium dan protein

\begin{abstract}
The objectives and benefits of this training to increase the protein intake with the processing of fresh water fish shredded. Processing the production of freshwater/catfish into a komonditi that can be sold at a higher price by being made into several kinds of processed catfish-based foods that meet the standards of food safety and health. This business is expected to be used as a pilot so that other farmers can participate in the place of business. Family Empowerment (PKK) catfish farmers in expanding marketing and to increase productivity. The power of receipt of freshwater fish to test organoleptic color, aroma, texture and flavor with long heating of different effect in real. From the test results the effectiveness to determine the best treatment of the heating done, obtained freshwater fish shredded with a long-warming 30 minutes.
\end{abstract}

Keyword : Freshwater fish, calcium and protein

\section{PENDAHULUAN}

\section{Latar Belakang}

Potensi hasil perikanan masyarakat desa bringkang kecamatan Menganti Kabupaten
Gresik dapat dioptimalkan dengan membuat produk pengolahan hasil pertanian dengan membuat abon berbahan dasar iakan air tawar dalam berwirausaha dibekali pengetahuan 
dan ketrampilan sebagai modal berwirausaha. Tersedianya bahan baku yang bisa dimanfaatkan untuk pembuatan produkproduk unggulan. Memberikan pelatihan ketrampilan membekali dengan kemampuan menciptakan lapangan pekerjaan sesuai dengan kompetensi bidang yang dipilih. Menciptakan materi pelatihan yang direview untuk memenuhi kebutuhan masyarakat. Beberapa materi yang dapat menjadi bekal pengetahuan dan pengalaman dalam membuka jenis wirausaha.

Potensi ekonomi dari produk yang di hasilkan oleh masyarakat akan menjadi mitra binaan masyarakat kampus, hal ini mengingat banyak order/pesanan dari masyarakat yang tidak dipenuhi oleh unit usaha UNIPA sehingga kemitraan ini sangat menguntungkan untuk kedua belah pihak. Terciptanya unit usaha di Wilayah Kecamatan Menganti Kabupaten Gresik. Meningkatkan nilai ekonomi masyarakat dan mengurangi tingkat pengangguran terutama pada generasi muda.

Kondisi profil kelompok sasaran di atas memberikan gambaran bahwa potensi pemberdayaan masyarakat sangat memungkinkan untuk dilaksanakan di desa Bringkang Kecamatan Menganti Kabupaten Gresik Jawa Timur . Mata pencaharian $40 \%$ masyarakat desa Bringkang adalah menjadi peternak lele. Meskipun dimasyarakat desa ini telah dinyatakan sebagai penghasil ikan lele terbanyak namun pengasilan dari beternak lele dirasa kurang memuaskan oleh para peternak hal ini disebabkan adanya perbedaan harga yang cukup besar antara harga di tengkulak dengan harga dipasaran. Pada waktu panen para peternak, hanya menjual hasil panen ikan kepada tengkulak dan mereka tidak memiliki upaya untuk diversifikasi hasil produk pasca panen sebagai upaya untuk meningkatkan nilai ekonomi hasil panen lelenya. Permasalahan yang dihadapi mitra adalah :

1) Hasil produksi peternakan pada saat musim panen sangat melimpah.

2) Harga jual ikan lele ditingkat tengkulak terdapat perbedaan besar dibandingkan dengan harga pasar $( \pm$ $\mathrm{Rp} 13.000,00 / \mathrm{kg}$ ).

3) Belum ada variasi pengolahan ikan lele pasca panen

4) Dokumentasi data keuangan belum tertata sehinggga menyulitkan dalam pengembangan usaha dan untuk memperoleh peminjaman modal untuk pengembangan usaha.

5) Luas wilayah pemasaran masih terbatas jangkauannya pada daerah Tarik.

Mengacu pada justifikasi prioritas penanganan bersama mitra, maka solusi utama yang akan diterapkan adalah :

1. Pengolahan hasil produksi ikan lele menjadi suatu komonditi yang dapat dijual dengan harga yang lebih tinggi dengan dibuat menjadi beberapa jenis olahan makanan berbahan dasar ikan lele yang memenuhi standart keamanan dan kesehatan pangan

2. Usaha ini diharapkan dapat dijadikan percontohan sehingga peternak yang lain ikut dapat menerapkan ditempat usahanya.

3. Pemberdayaan keluarga ( ibu-ibu PKK) peternak lele dalam memperluas pemasaran dan untuk meningkatkan produktifitas.

\section{TINJAUAN PUSTAKA}

\section{Ikan air tawar}

Ikan air tawar adalah sejenis ikan air tawar yang biasa dimakan oleh warga Asia Timur dan Asia Tenggara. Anggota suku Arcidae ini disebut ikan air tawar karena ia menghasilkan hemoglobin dalam cairan 
merah yang dihasilkannya, ikan air tawar merupakan jenis bivalvia yang hidup pada dasar perairan dan mempunyai ciri khas yaitu ditutupi oleh dua keping cangkang (valve) yang dapat dibuka dan ditutup karena terdapat sebuah persendian berupa engsel elastis yang merupakan penghubung kedua valve tersebut.

Ikan air tawar memijah sepanjang tahun dengan puncaknya terjadi pada bulan Agustus/September. Hewan ini termasuk hewan berumah dua. Kematangan gonad terjadi pada saat ikan air tawar mencapai ukuran panjang 18-20 $\mathrm{mm}$ dan berumur kurang dari satu tahun. Ikan air tawar merupakan salah satu jenis ikan air tawar yang mempunyai nilai ekonomis penting. Ikan air tawar mempunyai rasa yang gurih karena mengandung lemak dan kadar protein yang tinggi. Namun, pemanfaatan ikan air tawar saat ini masih terbatas dalam pengelolaannya sebagai bahan baku konsumsi ataupun pemanfaatan dalam bentuk lainnya.

Pengolahan ikan air tawar dilakukan dengan cara pengawetkan, penggaraman dan pengeringan. Pengawetan tersebut bertujuan untuk menghambat dan mencegah terjadinya kerusakan/mempertahankan mutu, menghindari terjadinya keracunan dan mempermudah penanganan serta penyimpanan.

\section{Kandungan gizi Ikan air tawar}

Menurut Moeljanto dan Heruwati (1995) diacu dalam Kasry (2017), ikan air tawar merupakan salah satu jenis ikan air tawar yang mempunyai nilai ekonomis penting dan disukai masyarakat. Selanjutnya Ismail (1995) diacu dalam Kasry (2017) mengatakan ikan air tawar mempunyai rasa yang guring karena mengandung lemak dan kadar protein yang tinggi. Komposisi kimia adalah air $83 \%$, lemak $0.91 \%$, protein $10.33 \%$ dan kadar abu $1.84 \%$. Ikan air tawar yang telah dewasa yang berukuran diameter $4 \mathrm{~cm}$ dapat memberikan sumbangan energi sebesar 59 kalori serat mengandung 8 gram protein, 1.1 gram lemak, 3.6 gram karbohidrat, 133 mg kalsium, $170 \mathrm{mg}$ phosfor, 300 SI vitamin A dan $0.01 \mathrm{mg}$ vitamin B1

Abon

Abon merupakan salah satu produk olahan yang sudah dikenal oleh orang banyak dan umumnya abon diolah dari daging sapi, sebab itu lebih dikenal oleh masyarakat luas. Pembuatan abon merupakan salah satu alternatif pengolahan, untuk mengantisipasi kelimpahan produksi atau untuk penganekaragaman produk.

Indonesia memiliki kekayaan perikanan yang beragam. Potensi produk perikanan Indonesia cukup besar. Usaha perikanan juka dikelolah secara professional, bukan hanya sebuah usaha sampingan sebatas pemenuhan kebutuhan hidup saja tetapi juga bisa menjadi usaha yang dapat memberikan suatu keuntungan yang sangat besar. Salah satu hasil perikanan yang bisa mendatangkan keuntungan besar adalah produk olahan dari ikan gabus dan ikan bandeng yaitu " Abon Ikan Gabus " dan "Abon Ikan Bandeng". Selain rasanya yang enak, gurih, juga sangat praktis dan mempunyai nilai gizi yang cukup tinggi

Abon sebenarnya merupakan produk daging awet yang sudah lama dikenal masyarakat.Data BPS (1993) dalam Slanturt (2000) menunjukkan bahwa abon merupakan produk nomor empat terbanyakdiproduksi.Abon termasuk makanan ringan atau lauk yang siap saji.Produk tersebut sudah dikenal oleh masyarakat umum sejak dulu.Abon dibuat dari daging yang diolah sedemikian rupa sehingga memiliki karakteristik kering. Pada umumnya daging yang digunakan dalam pembuatan abon yaitu daging sapi atau kerbau (Suryani et al, 2007)

Dalam pembuatan abon selain ikan yang juga digunakan sebagai bahan baku juga 
ditambahkan bumbu-bumbu seperti bawang merah, bawang putih, kemiri, lengkuas, ketumbar, dan cabai merah serta bahan tambahan makanan alami seperti garam, gula. Bumbu-bumbu dihaluskan diaduk rata dan dimasukkan bersama ikan dan santan kelapa, dimasak sehingga menghasilkan abon.Bahanbahan tersebut dapat memberikan cita rasa dan warna yang khas pada abon (Thomas, 1994).

Abon merupakan salah satu produk olahan yang sudah dikenal oleh orang banyak dan umumnya abon diolah dari daging sapi, sebab itu lebih dikenal oleh masyarakat luas. Pembuatan abon merupakan salah satu alternatif pengolahan, untuk mengantisipasi kelimpahan produksi atau untuk penganekaragaman produk.

\section{METODE PELAKSANAAN}

Mengacu pada justifikasi prioritas penanganan bersama mitra, maka solusi utama yang akan diterapkan adalah :

a. Tim akan datang ke lokasi (Mitra) satu minggu satu kali, yaitu hari Sabtu/Minggu sesuai dengan kesepakatan

b. Masing-masing penyuluhan dan pelatihan produk pasca panen dilakukan selama 4 jam

c. Dengan membagi peserta dalam 2 kelompok, maka masing-masing kelompok akan menerima penyuluhan dan workshop tentang pengolahan pasca panen lele berupa pembuatan abon dan kelompok pembuatan lele asap secara terstruktur sebanyak 5 kali. Diluar program yang terstruktur, peserta dihimbau melakukan latihan sendiri dibantu mahasiswa anggota tim.

d. Pada pertemuan pertama, peserta diberikan materi tentang manajemen pemasaran dan pengelolaan keuangan sederhana e. Pada pertemuan kedua, peserta diberikan materi tentang teori pembuatan produk berupa abon lele dengan variasi rasa dan ikan lele asap masing -masing disertai contoh variasi produk.

f. Pada pertemuan ketiga sampai kelima, para peserta dibimbing oleh seluruh anggota tim dan mahasiswa untuk latihan membuat pembuatan produk berupa abon lele dengan variasi rasa dan ikaan lele asap masing -masing disertai contoh produk. Pada pertemuan ini juga diberi pelatihan cara mengemas produk sehingga menarik konsumen

g. Pertemuan ke enam dilakukan evaluasi kegiatan yang telah dilakukan dan dibahas keberlanjutan dari program ini.

\section{Partisipasi Mitra Dalam Pelaksanaan Program}

Selama pelaksanaan program, pengusaha mitra berperan sebagai :

a. Menyediakan lahan untuk lokasi kegiatan pengabdian.

b. Penyedia ruang pertemuan pada saat pelatihan.

c. Mengkoordinir peserta supaya bersedia hadir dan tetap mengikuti pelatihan sampai dengan tuntas.

d. Menyediakan bahan pembuatan abon dan ikan lele asap.

Ikan air tawar lele, sebagai bahan makanan yang mengandung protein tinggi dan mengandung asam amino esensial yang diperlukan oleh tubuh. Absorpsi protein ikan lebih tinggi dibandingkan daging sapi, ayam, dan lain-lain. Di samping itu nilai biologisnya mencapai $90 \%$, dengan jaringan pengikat sedikit sehingga mudah dicerna.Oleh karena itu Ikan air tawar dan hasil produknya banyak dimanfaatkan oleh orang-orang yang mengalami gangguan pencernaan sebab mudah cerna (Adawyah, 2007). 
Berdasarkan hal tersebut, Ikan air tawar mempunyai potensi yang cukup baik, akan tetapi belum diolah secara maksimal. Sebagaimana kita ketahui sebagian besar diolah secara konvensional seperti ikan lele yang hanya digoreng biasa saja sebagai lauk pauk. Salah satu alternatif untuk mengatasi hal tersebut maka ikan dapat diolah menjadi abon.

Abon merupakan salah satu bentuk olahan hasil perikanan yang daya simpannya tinggi dan dapat dikonsumsi sebagai lauk pauk juga sebagai pengisi berbagai kue misalnya lemper, pastel, dan lain sebagainya. Abon ikan diolah dari campuran daging ikan yang dikukus terlebih dahulu dan dipisahkan antara daging dengan kulit, duri dan tulangnya, kemudian ditambahkan santan dan bumbu yang dimasak sampai kering sehingga berbentuk seperti abon. Pada umumnya, abon yang dikenal adalah abon daging sapi, kemudian dikembangkan dan mengganti dengan Ikan air tawar terutama Ikan air tawar yang memiliki daging tebal dan yang memiliki nilai ekonomis (Rabiatul Adawiyah, 2006)

Persentase berat kalsium pada Ikan air tawar secara umum adalah 0.1-1.0\%, dimana rasio kalsium dan fosfor adalah 0.7-1.6. Saat tubuh sangat membutuhkan kalsium dan berada pada kondisi optimal, 30-50\% kalsium yang dikonsumsi dapat diabsorpsi tubuh, sedangkan pada kondisi normal, penyerapan sebesar 20-30\% dianggap baik, dan kadangkadang penyerapannya hanya mencapai $10 \%$. Pada masa pertumbuhan anak, penyerapan dapat mencapai $75 \%$ dari makanan berkalsium. Agar kalsium dapat digunakan tubuh, maka kalsium tersebut harus dapat diserap oleh tubuh terlebih dahulu. Terdapat beberapa faktor yang dapat mempengaruhi penyerapan kalsium, yaitu : (1) keberadaan asam oksalat dan asam fitat, (2) keberadaan serat yang dapat menurunkan waktu transit makanan dalam saluran cerna sehingga mengurangi kesempatan untuk absorpsi, (3) rendahnya bentuk aktif vitamin D, (4) keseimbangan rasio fosfor dan kalsium, (5) kompleksitas struktur dan konfigurasi protein.

Penelitian ini akan mempelajari komposisi yang terbaik sehingga menghasilkan Abon Ikan air tawar yang baik dari kandungan gizi terutama protein dan kalsium daya terima panelis terhadap produk ini.

\section{HASIL DAN PEMBAHASAN}

\section{Pengolahan produk pasca panen ikan lele}

Produksi lele pada saat panen oleh peternak akan dijual kepada tengkulak harga lebih murah dibandingkan dengan harga pasar oleh karenanya ikan lele perlu diolah menjadi produk yang mempunyai nilai ekonomi yang tinggi dan usia simpan lebih lama (tidak cepat rusak/ busuk jika tidak terjual habis akan cepat rusak dengan dibuat abon lele dan lele asap disamping dijual berupa ikan lele. Abon lele usia simpannya lebih lama sampai 6 bulan sedangkan lele asap dapat bertahan 2 minggu - 1 bulan sehingga peternak dapat memperluas daerah pemasaran untuk meningkatkan produktifitas.

Metode pendekatan yang ditawarkan untuk mendukung realisasi program $\mathrm{I}_{\mathrm{b}} \mathrm{M}$ adalah dengan cara penyadaran kepada kelompok peternak lele akan pentingnya pengolahan pasca panen menjadi produk yang mempunyai nilai jual lebih tinggi, melakukan pembukuan usaha dan srtategi pemasaran. 
1. Abon ikan lele

\begin{tabular}{|l|l|l|l|}
\hline & & & \\
\hline
\end{tabular}
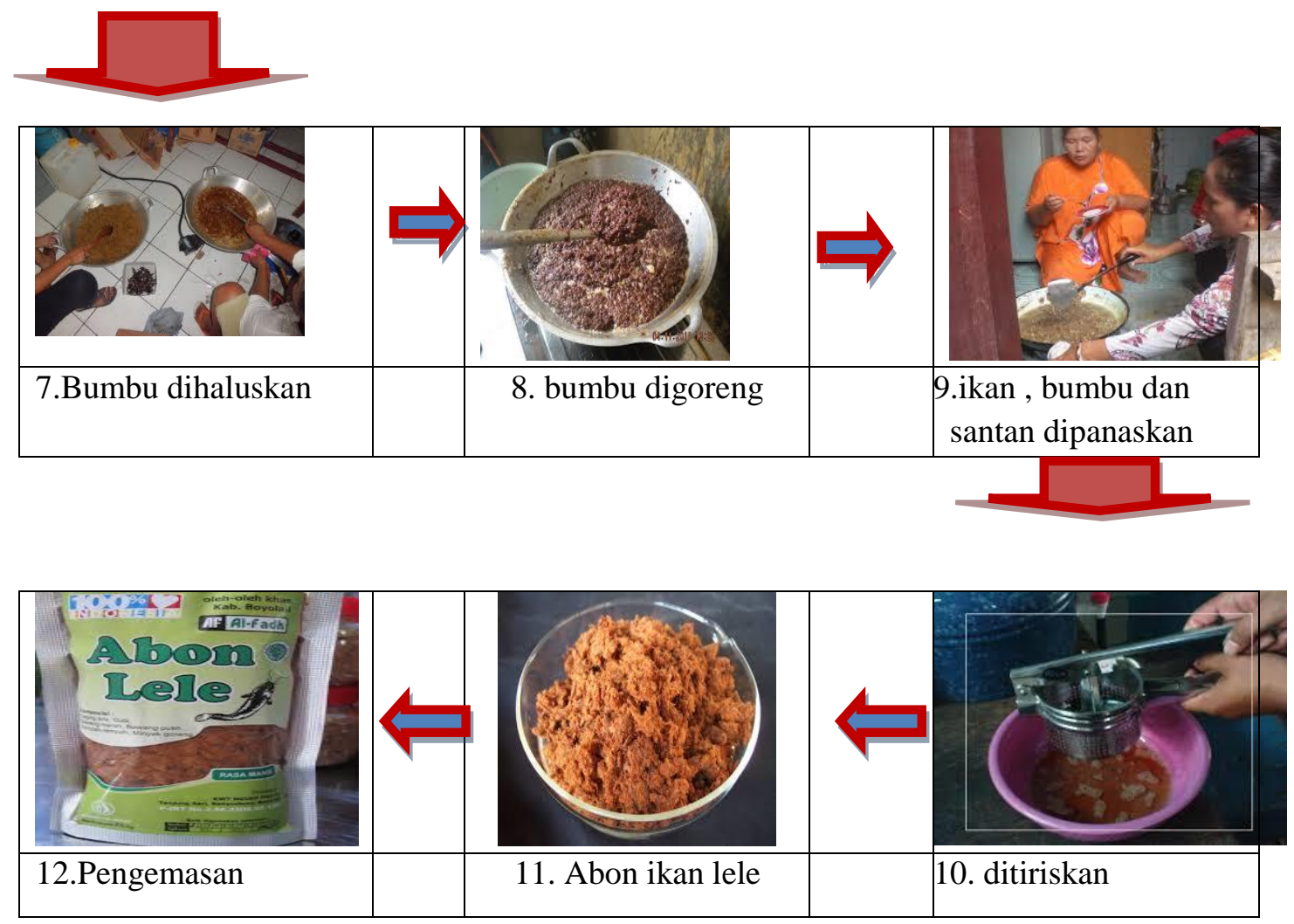

Gambar 1: Proses pembuatan abon ikan lele 
Keterangan:

1. Alat : pisau, ember, wajan, kompor, alat pengaduk, panci kukus, panci, pastik

2. Cara Membuat Abon Ikan Lele

a. Ambil ikan lele 10 ekor $( \pm 1.800$ gram) bersihkan, digoreng, disuwir ambil dagingnya

b. Kukus ikan sampai matang ( \pm 1 jam)

c. Pisahkan daging ikan dengan durinya

d. Daging ikan dihaluskan

e. Haluskan bumbu-bumbu 3 butir bawang merah, 2 siung bawang putih, 2 butir kemiri, disangrai, 1 sendok teh ketumbar bubuk kecuali batang serai dan daun salam kemudian digoreng sampai matang

f. Tuangkan santan dimasak sampai mendidih kemudian masukkan daging ikan lele sambil terus diaduk sampai matang dan mengering

g. Abon ikan Lele sudah siap . Untuk memperluas pasar perlu dibuat abon rasa : abon rasa pedas, manis dan rasa gurih.

\section{Pemberdayaan penternak lele dalam diversifikasi pengolahan lele}

Penerapan IPTEKS ini akan menyelesaikan 3 masalah sekaligus, yaitu masalah pengolahan dengan diversifikasi produk baru yang memenuhi standart kesehatan keamanan pangan, pembukuan sederhana dan perluasan pemasaran

Metode pendekatan yang ditawarkan untuk mendukung realisasi program pengabdian masyarakat adalah dengan cara penyadaran kepada kelompok peternak lele akan pentingya pengolahan pasca panen menjadi produk yang mempunyai nilai jual lebih tinggi.

Metode yang digunakan untuk mencapai tujuan kegiatan ini adalah sebagai berikut:

1. Untuk mengatasi permasalahan mitra solusi yang ditawarkan dengan pengolahan produk pasca panen dengan pembuatan produk abon ikan lele yang memenuhi standart keamanan dan kesehatan pangan agar masyarakat dapat memperoleh manfaat secara ekonomis. Adapun rincian kegiatan untuk metode ini adalah sebagai berikut :

a. Penjelasan tentang cara pembuatan abon ikan lele

b. Penjelasan tentang cara pembuatan ikan lele asap

c. Persiapan peralatan pembuatan abon ikan lele dan ikan lele asap

d. Pelatihan pembuatan abon ikan lele dan ikan lele asap

2. Solusi ke 2 untuk mengatasi, yaitu: pemberdayaan peternak lele dalam memperluas jaringan pemasaran untuk meningkatkan produktifitas dan pembukuan sederhana. Adapun rincian kegiatan untuk metode ini adalah sebagai berikut :

a. Pemberian materi strategi penjualan

b. Pemberian materi pembukuan sederhana.

3. Untuk selanjutnya pelaksanaan monitoring dan pelaporan dilakukan sebagai berikut :
a. Pelaksanaan monitoring kegiatan.
b. Laporan hasil penerapan tehnologi pada kegiatan $\mathrm{I}_{\mathrm{b}} \mathrm{M}$.


c. Laporan hambatan \& tingkat keberhasilan program pada kegiatan $\mathrm{I}_{\mathrm{b}} \mathrm{M}$.

d. Laporan hasil pemasaran abon ikan lele dan ikan lele asap

e. Evaluasi Kegiatan.

f. Pembuatan laporan kegiatan.

4. Hasil dan Pembahasan

\section{Target luaran}

\section{Jenis Luaran Yang Akan Dihasilkan}

Selesainya pelaksanaan program pengabdian masyarakat prodi PKK FKIP Universitas PGRI Adi Buana Surabaya diharapkan mampu memberdayaan ibu-ibu PKK Desa Bringkang dalam pembuatan abon lele dengan teknologi dan manajemen pemasaran dan pembukuan sederhana.

Luaran yang akan dihasilkan dari penerapan IbM ini berupa produk yaitu:

1. Kesadaran masyarakat akan pentingnya kebersihan dalam pengolahan makanan (terutama abon lele) sehingga amam bagi kesehatan .

2. Abon lele dan ikan lele asap yang memenuhi standart kesehatan dan keamanan pangan

3. Pembukuan Sederhana

4. Perluasan Pemasaran

Adapun dampak dari penerapan IPTEKS (IbM) ini adalah :

1. Warga masyarakat dapat memanfaatkan ikan lele yang melimpah diolah menjadi abon lele yang memenuhi standart keamanan pangan Warga masyarakat dapat memperluas pemasaran abon lele dan ikan lele asap yang diproduksi.

2. Pengolahan hasil produksi ikan lele menjadi suatu komonditas yang dapat dijual dengan harga yang lebih tinggi dengan dibuat menjadi beberapa jenis olahan makanan berbahan dasar ikan lele yang memenuhi standart keamanan dan kesehatan pangan

3. Usaha ini diharapkan dapat dijadikan percontohan sehingga peternak yang lain ikut dapat menerapkan ditempat usahanya.

4. Pemberdayaan keluarga ( ibu-ibu PKK) peternak lele dalam memperluas pemasaran dan untuk meningkatkan

\section{KESIMPULAN}

\section{Simpulan}

Hasil pengabdian masyarakat

1. Hasil pengabdian masyarakat memberdayaan ibu-ibu PKK Desa Bringkang dalam pembuatan abon lele dengan teknologi dan manajemen pemasaran dan pembukuan sederhana

2. Daya terima masyarakat terhadap abon ikan air tawar menunjukkan bahwa untuk aroma, warna, rasa maupun tekstur, warga lebih menyukai abon ikan air tawar dengan lama pemanasan 30 menit. Daya terima abon ikan air tawar untuk uji organoleptik warna, aroma, tekstur dan rasa dengan lama pemanasan yang berbeda berpengaruh secara nyata

3. Dari hasil uji efektivitas untuk menentukan perlakuan terbaik dari pemanasan yang dilakukan, diperoleh abon ikan air tawar dengan lama pemanasan 30 menit.

\section{Saran}

1. Ikan air tawar memiliki banyak manfaat dan memiliki kandungan zat gizi yang tinggi, untuk itu perlu diolah agar dapat menjadi produk yang lebih bervariasi. Perlu diadakan upaya pengolahan lebih lanjut untuk 
mengetahui kadar zat gizi lain yang ada pada produk tersebut dalam bidang penganeka ragaman pangan dalam bidang gizi.

2. Penelitian lebih lanjut diversifikasi pengolahan pengawetan ikan air tawar yang tepat dengan berbagai hasil olahan yang mempertahankan nilai gizi ikan air tawar untuk mempertahankan nilai gizi ikan air tawar

\section{REFERENSI}

Almatsier, Sunita. 2004. Prinsip Dasar Ilmu

Gizi. Bandung : PT.Gramedia Pustaka Utama.

Anomin ${ }^{1}$ Udang Jerbung http://www.udangjerbung.com.

DUNIA PERIKANAN DAN KELAUTAN INDONESIA, 2010. Diakses 20 Januari 2012.

Anonim $^{6}$. 2009. Sifat-Sifat Daging Segar. http://cinnatalemieneabustam.blogspot.com/2009/03/sifatsifat-daging.html. Diakses 3 Agustus $\underline{2012}$

Apriyantono, Anton. 1989. Analisis Pangan. Bogor : PT. Penerbit IPB (IPB PRESS).

BappenasRI. 2007. Rancana Akzi Nasional Pangan dan Gizi. Jakarta.

Budiyanto, MAK. 2004. Dasar-dasar Ilmu

Gizi. Makalah, Universitas Muhammadiyah, Malang.
Damayanti, Evi Sri Anna Majilati. 1997. Diktat Percobaan Makanan. Bogor : IPB.

De Man, Jhon M. 1997. Kimia Makanan. Bandung : ITB.

Departemn Kesehatan RI. 2001. Program Penanggulangna Pangan dan Gizi. Jakarta, Direktorat Gizi Masyarakat.

Departemen Kesehatan RI Depkes, RI. 1995.

Daftar Komposisi Bahan Makanan (DKBM).Jakarta :DepkesRI.

Departemen Kesehatan RI 1995. Daftar

Komposisi Gizi Pangan

Indonesia.Jakarta :DepkesRI.

Jolane Abrams. 2010. DNA, RNA, and Protein : Life at its simplest. http://www.postmodern.com/ jka/rna world/nfrna/nf-rnadefed.html. Diakses 21 Desember 2011.

Majalah Kesehatan Anak.

http://www.anemia.com. Diakses 15 Januari 2012.

Persagi.2005. Daftar Komposisi Bahan Makanan. Jakarta : Persagi.

Rahman.

http://www.kompas.com/kesehatan/06

01/09/103923.html. Diakses 23

Desember 2011.

Sediaoetomo, Achamd Djaelani. 2004. Ilmu Gizi - Untuk Mahasiswa Dan Profesi

Di Indonesia. Jakarta : PT.Dian Rakyat.

Winarno, F, G. 2002. Kimia Pangan dan Gizi. Jakarta : Gramedia Pustaka.

Winarno, F, G. 2004. Kimia Pangan dan Gizi. Jakarta : Gramedia Pustaka 
PENAMAS ADI BUANA

Volume 3, Nomor 2, 01 Januari 2020
p-ISSN 2622-5727

e-ISSN 2622-5395 